\title{
The Effect of Type A Personality Trait and Mental Well-Being on Task Performance: A Research on Five-Star Hotel Managers in Alanya
}

\author{
A Tipi Kişilik Özelliği ve Mental İyi Oluşun Görev Performansı Üzerindeki Etkisi: \\ Alanya'daki Beş Yıldızlı Otel Yöneticileri Üzerine Bir Araştırma
}

\author{
Doktora Öğrencisi Sefa CEYHAN ${ }^{1} 1$
}

\begin{abstract}
Providing qualified service in the service sector where emotional variables are at the forefront is closely related to the mental well-being of managers. However, it is not possible to state that every manager with high mental well-being will provide high performance. Every positive and negative attitude of the managers is interpreted by both subordinates and hotel customers, and the next step is taken according to this interpretation. Therefore, managers' personality traits are also an important factor for performance. In line with this importance, determining the effect of type a personality traits and mental well-being on task performance constitutes the purpose of the research. The research was conducted in Alanya since there has not been a similar study in destination. In accordance with research purpose data set of 154 people obtained by the face-to-face survey method was evaluated. According to result of the research, it was seen that a-type personality traits have a positive relationship and effect on the dimension of importance attached to speed and mental well-being on task performance. Result is important in terms of theoretical and practical contribution in terms of considering type a personality not only with negative qualities such as stress or cynicism, but also in terms of performance and mental well-being.
\end{abstract}

Keywords: Type A personality trait, mental well-being, task performance, hotel managers

Paper Type: Research

$\ddot{\mathbf{O} z}$

Duygusal değişkenlerin ön planda olduğu hizmet sektöründe nitelikli hizmet sunulması, yöneticilerin mental iyi oluşuyla yakından ilişkilidir. Ancak mental iyi oluş düzeyi yüksek olan her yöneticinin yüksek performans sağlayacağını ifade etmek mümkün değildir. Yöneticilerin olumlu ve olumsuz her tutumu hem astlar hem de otel müşterileri tarafından yorumlanmakta ve bir sonraki adım bu yoruma göre atılmaktadır. Dolayısıyla yöneticilerin kişilik özellikleri de performans için önemli bir unsurdur. Özellikle hizmet sektöründe yaşanan yüz yüze iletişim sebebiyle bu önem derecesinin daha yüksek olduğu ifade edilebilir. Öyle ki yöneticilerin kişilik, mental iyi oluş gibi duygusal değişkenlerinin belirlenmesi ve yapılan işin nicelik ve nitelik bağlamında dikkate alınması söz konusu önemi arttırıcı nitelik taşımaktadır. $\mathrm{Bu}$ önem doğrultusunda, a tipi kişilik özellikleri ve mental iyi oluşun görev performansı üzerindeki etkisinin belirlenmesi araştırma amacını oluşturmaktadır. Araştırma amacı doğrultusunda yüz yüze anket yöntemi ile elde edilen 154 kişilik veri seti değerlendirmeye alınmıştır. Elde edilen bugulara göre; A tipi kişilik özelliklerinin hıza verilen önem boyutu ve mental iyi oluşun görev performansı üzerinde pozitif yönlü ilişki ve etkiye sahip olduğu tespit edilmiştir. Bu sonuç ilgili literatürde yer alan A tipi kişiliğin sadece stress, sinizm ve tükenmişlik gibi olumsuz kavramlarla değil aynı zamanda performans arttırıcı ve mental iyi oluşu yordayıcı nitelikler bağlamında ele alınması bakımından dikkate değer katkılar sunmaktadır.

Anahtar Kelimeler: A tipi kişilik özelliği, mental iyi oluş, görev performansı, otel yöneticileri

Makale Türü: Araştırma

${ }^{1}$ Burdur Mehmet Akif Ersoy Üniversitesi, Sosyal Bilimler Enstitüsü, ceyhansefa@ @otmail.com.

Atıf için (to cite): Ceyhan, S. (2021). The effect of type A personality trait and mental well-being on task performance: A research on five-star hotel managers in Alanya. Afyon Kocatepe Üniversitesi Sosyal Bilimler Dergisi, 23(4), 1538-1554. 


\section{Introduction}

Businesses require qualified personnel in order to resist competition and protect themselves (Tağraf, 2009). This need is especially experienced in the tourism sector. As a matter of fact, the labor-intensive structure of the tourism sector reveals the importance of the human factor and service quality (Kozak, 2001). The fact that individuals working in hotel businesses have different cultures and values makes this human factor even more important (Yin-Fah, Foon, Chee-leong \& Osman, 2010; Su, 2014; Zopiatis, Constanti \& Theocharous, 2014). Actually, it is well-known that organizational success or failure is directly related to the importance given to the human factor in the contemporary management approach (Serbest, 2000). The way to ensure managerial success is that the manager finds the energy and interaction required to meet the needs of his subordinates (Uslu, 2011). The energy and interaction in question should be taken into consideration especially in hotel management since the department managers, such as the front desk, food and beverage and housekeeping, who are in close contact with the guests face-to-face, have to work directly with the focus on guest satisfaction. It is possible that this satisfaction provided in the hotel management will be reflected by the subordinates as an example. At this point, the feedback process, in which emotional variables are at the forefront and managers are afraid of confronting their subordinates and making false communication, is an important element for performance. (Hatipoğlu, Akduman \& Demir, 2019). In addition, it can be stated that, when miscommunication is eliminated, problems such as imbalance between individuals or slowing down work will be eliminated, and efficiency and effectiveness will increase. Therefore, researches show that individuals with high psychological and physical health levels have high mental well-being as well (Keyes, 2005; Keyes, Myers \& Kendler, 2010). In addition, it is among the results of the relevant research that these individuals establish good relations with other people and are more productive at work than others (Lyubomirsky, King \& Diener, 2005; Keldal, 2015). From this point of view, it is necessary to carry out studies and offer suggestions to determine the effect of both well-being and personality on performance, which is an important element in fulfilling organizational goals (Hogan, 1944; Viswesvaran \& Ones, 2000). Therefore, this study will provide the relevant literature because the related variables have not been studied together. In addition, the findings obtained as a result of the research offer suggestions to practitioners. In line with this importance, this study aimed to determine the effect of type a personality traits and mental well-being on task performance.

\section{Literature Review}

\subsection{Type A Personality Traits}

The concept of type is expressed as a set of social phenomena, behavior or physical qualities clustered according to individual characteristics (Tatar, 2017). In this context, there are some personality typologies developed by researchers (Keenan \& McBain, 1979; Howard, Kopta, Krause \& Orlinsky, 1986; Dembroski \& Costa, 1987; Al-Mashaan, 2001). Kretschmer's personality typology is one of them. According to Kretschmer, there are three personality typologies as athletic, asthenic and pyknic (Stevenson, Sung, Pai \& Lyman, 1937). Athletic type individuals are muscular, medium height individuals with long arms and legs. Asthenic types are tall and thin individuals. These individuals are generally weak, cool and introverted. Individuals with a picnic type personality are of medium height, short neck, wide abdominal cavity and tendency to get fat (Köknel, 2005). When the personality typology of Eric Fromm (1944) is examined, two dimensions, namely biophilia and necrophilia, are encountered. According to Fromm, the vast majority of people have both of these orientations in their personalities to a certain extent. In addition, the conflict between these two trends is characterized as the source of a productive development (Fromm, 1942). Another typology is the personality typology of Alfred Adler (1964), which is evaluated in four dimensions: ruling, leaning, avoiding and socially useful. The ruling type individuals adopt a pragmatist lifestyle. 
The leaning type refers to individuals who have an indifferent attitude towards the outside world and expect everything from others.

The avoiding type does not have sufficient social interest and is not capable of facing their own problems. Individuals in this typology fear failure rather than success. Socially useful type refers to individuals who have reached the required maturity level and are developed. Socially useful individuals have a high degree of social interest and competence, and they tend to be close to other people (Adler, 1964). Personality typology, which is the subject of this research, is a and b type personality structure. type a personality (Luthans, 2011), proposed by Freidman and Rosenman in the 1950s, describes the common characteristics of individuals who are overly ambitious, over-eager for financial gains and tend to do many jobs in a short time (Rayburn \& Rayburn, 1996).

Price (1982) suggests that there are two types of fear mechanisms in individuals with type a personality trait. The first of these fear mechanisms is the anxiety of proving oneself. At this level, the individual is extremely competitive and challenging, feeling that he must always work hard. The second is the idea that under all circumstances, the good, which is formed with the concern that moral principles are not valid, will expel the bad. This thought triggers a person's sense of competitiveness and leads to intolerance (Özcan \& Behram, 2013). For this reason, individuals with type a personality trait are ambitious, inclined to complete too many tasks in a short time, anxiety to prove themselves and are constantly increasing goal-oriented (Rayburn \& Rayburn, 1996). Type b personality trait expresses the opposite behaviors of type a. Type $b$ individuals are unhurried, not under time pressure and patient. However, this does not make them careless or indifferent. Type $\mathrm{b}$ individuals also work hard and want success and performance. The main difference between the two is the perception of stress that emerges regarding whether the individual feels pressured or not (Burger, 2006). Type b individuals with a low perception of stress in question know their emotions well, think a lot in a balanced way and are open to innovation. In addition, they do not like heavy workloads and they do not have any concerns about appearing flawless (Tarhan, 2012).

When the literature is examined, there are some studies on the positive effect of personality on performance. For example, in the study of Güvendi, Işım \& Güçlü, (2018), the relationship between personality traits, psychological performance and decision-making styles was examined and it was found that there was a significant and positive relationship between all variables. In another study by Gözmen \& Aşçı (2016), optimal performance, personality traits and perfectionism were examined and it was found that personality and perfectionism predicted optimal performance mood. In another study on the relationship between personality and performance in organizational life, it was found that positive activity plays a mediating role between personality and task performance (Harmanc1, 2018). However, these studies are based on five factor personality traits rather than studies on type $a$ and $\mathrm{b}$ personality traits. $\mathrm{A}$ and $\mathrm{b}$ type personality has been studied extensively on concepts such as burnout, cynicism, and stress, and findings regarding their effect on these concepts have been obtained (Ceyhan \& Çiçek, 2020; Batıgün \& Şahin, 2006). At this point, the question of what effect type a personality structure has on task performance is encountered. Based on the problematic, the first hypothesis of the study was formed as follows in order to determine the positive effect of type a personality trait on task performance; " $H_{l}$. Type-a personality traits has positive effect on task performance."

\subsection{Mental Well Being}

There are mental activities that include the cognitive and affective tools used by the individual to make sense of life (Kottke, Stiefel \& Pronk, 2016). One of these activities is the creation of well, which is based on the mental aspect of human nature and is one of the concepts of positive psychology (Demirtaş, Baytemir \& Güllü, 2018). Well-being, which was first conceptualized by the World Health Organization (WHO) in 1948, is the recognition of 
abilities, living a purposeful and meaningful life, contributing positively to society, establishing positive relationships with other individuals, inner peace, happiness and joy, with the ups and downs of life. In another words, defined as the capacity to cope and take responsibility. Based on this definition, it can be stated that well-being is a multifaceted structure that represents both individual and environmental aspects of the individual and at the same time gives pleasure to the individual. The concept of well-being, which has been the subject of discussions due to its pleasure-oriented nature, has been evaluated in two dimensions: subjective and psychological. In the hedonic dimension of subjective well-being, individuals emphasize their positive emotions, and experience negative emotions less than positive emotions (Ryan \& Deci, 2001). Subjective well-being of individuals takes place in two stages as cognitive and emotional. While the satisfaction of the individual from life constitutes the cognitive stage, each of the positive and negative emotions is located in the emotional stage (Diener \& Suh, 1997). In the oedonomic dimension of psychological well-being, individuals seek meaning and purpose in life, accept themselves and be in positive communication with other people (Ryan \& Deci, 2001). According to Ryff \& Singer (2008), psychological well-being has features such as positive relationships with other people, meaning of life, self-acceptance, environmental dominance, and personal development. At this point, the interaction of self-determination theory (SD) between the individual and the social context is important. So much so that the positive inference as a result of the support of the individual in the said interaction and negative inference as a result of its prevention is determinant in determining the level of mental well-being. Therefore, the social and individual needs of individuals should be met for their mental health (Deci \& Ryan, 2000). The theory of expanding and building emotions (Fredrickson, 2009) can also be a guide in meeting these needs. Negative emotions such as anxiety and anger set limits in the interaction between the individual and the social context.

People are ready to protect themselves. On the other hand, positive emotions constitute cognition and action spirals and become a permanent personal resource for social and individual development (Carr, 2016). Studies support this situation. For example, subjective well-being and strong character (Yasmin \& Khan, 2017), interpersonal competence (Baytemir, 2016), life goals, needs and satisfaction (İlhan \& Özbay, 2010) presents important findings at the point. In this case, it can be stated that individuals with high mental well-being will have high mental and physical health (Keyes, 2005; Keyes, et al., 2010), and will establish positive relationships with other individuals, whose success and productivity will increase (Lyubomirsky et al., 2005; Keldal, 2015). Mental well-being is known to be associated with self-understanding (Imtiaz \& Kamal, 2016), conscious eating (Khan \& Zadeh, 2014), life satisfaction (Diener \& Chan, 2011), meaning in life (Liang, Lan-xiang, si-jie, \& Wu, 2017) and social support (Fuller-Iglesias, 2015). In addition, in a study conducted by Yaşin (2016), a positive effect of the precursors of positive psychology on employee well-being and performance was found. Based on these theoretical and empirical inferences, the second hypothesis of the research was formed as follows; " $H_{2}$. Mental well-being has positive effect on task performance."

\subsection{Task Performance}

Performance refers to the productivity of the individual regarding the job he / she is in or doing (TDK, 2020). Professional quality, suitable working conditions, clearly defined job description and moral characteristics are very important in high productivity (Özdevecioğlu \& Kanıür, 2009). In line with this importance, the factors that determine the performance level, performance management and evaluation issues are widely available in the literature (Hatipoğlu et al., 2019). Studies have suggested that performance is a multidimensional structure and should be considered in the context of three types of organizational behavior (Sonnentag \& Frese, 2002; Viswesvaran \& Ones, 2000). The first of these is organizational citizenship behavior. Organizational citizenship behavior that has reached its present state with the theory of satisfaction performance (Podsakoff, McKenzie, Paine \& Bachrach, 2000; DiPaola \& Hoy, 2005; Katz; 1964) is a set of voluntary behaviors that contribute to the active functioning of the 
organization and are not included in the employee's job description (Podsakoff et al., 2000). In other words, it is the employee's voluntary over-role behaviors (Organ, 1988). The second is counterproductive work behaviors, which express the exact opposite of organizational citizenship behavior. These behaviors are deliberate and deliberate actions of the members of the organization that are against the interests of the organization (Sacket \& DeVore, 2001). The last type of behavior is contextual and task performance. Contextual performance, also known as citizenship behavior, relates to activities that are not directly related to work and job duties. These activities include working as a collaborator and volunteering to complete task activities that are not within the formal role and task (Borman \& Motowidlo, 1997). The expression volunteering here is an individual effort that is not directly related to the individual's main tasks. In this case, contextual performance is a voluntary intermediary for the effective and efficient performance of the tasks that need to be done within the organization (Diaz-Vilela et al., 2015). Contextual performance is classified into three categories according to Goodman \& Svyantek (1999). The first of these is that contextual performance contributes spiritually to both the organization and the individual. Second, contextual performance is focused on behavioral role. The last one is that contextual performance emerges in individuals depending on the will (Jawahar \& Ferris, 2011). On the other hand, task performance expresses the reason for the employee's presence in the organization. In other words, task performance refers to the implementation behavior and results in the fulfillment of organizational goals and objectives (Viswesvaran \& Ones, 2000).

Task performance can be examined in two ways, individual and situational. Individual performance is the quality and amount of output expected from the individual as a result of blending his experience and abilities with his individual efforts and behaviors (Pekdemir \& Koçoğlu, 2014). According to this, it can be mentioned that the higher the knowledge, skills, and experiences of the individual, the higher the performance expected from him will increase in the same proportion. Situational performance is determined by the importance or characteristics of the work done, role ambiguity, conflict, and stress factors in the work environment (Sonnentag \& Frese, 2002). Furthermore, task performance has two dimensions. They are technical-administrative task performance and leadership task performance (Mohammed \& Bartlett, 2002). Technical-administrative task performance includes situations such as stationery, paperwork, business decisions, planning or quality. Leadership and task performance are issues related to supervision, human and team management (Conway, 1999). The research model created in line with the purpose and hypotheses of the study is presented in Figure 1.

Figure 1. Research model

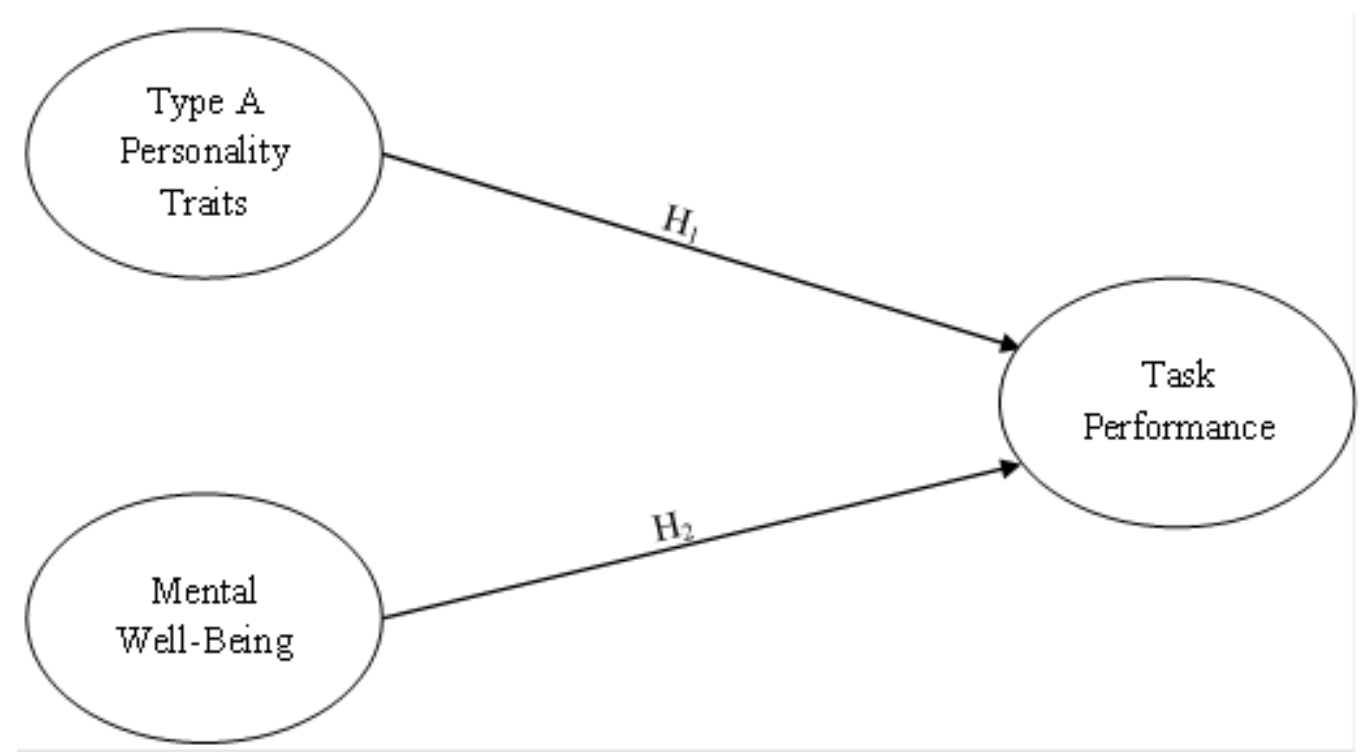




\section{Methodology}

\subsection{Sample and Data Collection}

This study was approved by the Ethics Committee of Burdur Mehmet Akif Ersoy University in accordance with decision number GO 2020/338. The research was carried out in five-star hotel establishments in Alanya district of Antalya province in January and February of 2021. The main reason for conducting the research in the mentioned hotel businesses is that approximately 50\% (340) of the 685 five-star hotels in Turkey operate in the province of Antalya (KTB, 2017) and these activities are also intensely applied in Alanya. The reason for choosing five-star hotel businesses is the idea that their management approach will be topnotch. As of the end of 2020, there are 84 five-star hotels in Alanya district (Altso, 2019; Altid; 2020). Front office, food and beverage and housekeeping managers who work in these hotels and are in close contact with guests, form the research universe. The reason why the research universe is chosen within the scope of the relevant managers is the obligation of hotel businesses to work with a focus on guest satisfaction and the thought that this obligation is realized primarily at the management level. As a matter of fact, the guest satisfaction provided at the management level is likely to be reflected by the subordinates as an example. In this context, contacts were made with managers who are actually working or who are on hold due to the closed season and epidemic. As a result of this contact, 67 of 84 hotels were reached. At the end of this process, $67 \times 3=201$ people covering these three departments were accepted as the universe with 5\% margin of error (Can, 2018). The face-to-face survey study was applied with the convenience sampling method, one of the non-random sampling methods, 157 participants were reached within the bounds of possibility, and 154 questionnaires filled out completely were taken into consideration.

\subsection{Measures}

In the questionnaire form, which is used to collect research data, there are questions expressing demographic characteristics of the participants firstly. Then, in order to measure atype personality traits, the type-a personality traits questionnaire developed by Rathus \& Nevid (1989) and adapted into Turkish by Batıün \& Şahin (2006) was used. The scale consists of 24 questions and 4 dimensions. The dimensions in the questionnaire are as follows; importance attached to work, avoiding social activities, importance attached to speed and importance attached to timing. The scale developed by Goodman \& Svyantek (1999) was used to measure the performance of the participants who answered personality questions. In this scale, the participant evaluates his/her own performance. It was seen that the Cronbach Alpha reliability coefficient of the scale, which was used in national and international studies, ranged from 0.78 to 0.93 (Polatc1, 2014; Özdevecioğlu, Mahmut \& Karaca, 2014; Bakker, Demerouti \& Lieke, 2012; Sparrow, Chadrakumara \& Perera, 2010). The translation of Bağc1 (2014) was used in adapting the scale to Turkish. In the last part, Warwick-Edinburgh Mental Well-Being Scale (WEMWBS) was used. The scale in question was developed by Tennant et al., (2007) to measure the mental well-being levels of individuals living in England. WEMWBS consists of 14 items and deals with individuals' positive mental health by including psychological wellbeing and subjective well-being. The scale is in the 5-point Likert type. The Cronbach Alpha reliability coefficient of the scale is 0.83 . There is no reverse question on these dimensions. In addition, all of the questionnaires were applied in a 5-point Likert system as in their original forms.

\section{Research Findings and Interpretation}

Statistical software's were used in the analysis of the research data. Firstly, demographic information about hotel managers participating in the study was presented, then Cronbach's Alpha $(\alpha)$ values were used for the reliability analysis of the data obtained as a result of the research. Normality analysis was performed to determine whether the data showed normal distribution (Skewness - Kurtosis). After the relevant normality distributions were found 
to be sufficient, exploratory and confirmatory factor analysis (CFA) was used to explain the relationship between observed and latent variables (İhan \& Çetin, 2014). Finally, Pearson Correlation analysis was applied to determine the relationships between task performance and mental well-being, the importance attached to work, moving away from social activities, the importance attached to speed and timing, which constitute the dimensions of type a personality trait. Multiple Regression Analysis was conducted to determine the effect.

\subsection{Demographic Findings of Participants}

Statistical findings regarding the demographic findings of the managers participating in the study are included in Table 1.

Table 1. The descriptive profile of the participants

\begin{tabular}{|c|c|c|c|c|c|c|c|}
\hline Variables & $\mathrm{n}=154$ & $\mathrm{~F}$ & $\%$ & Variables & $n=154$ & $\mathrm{f}$ & $\%$ \\
\hline \multirow{2}{*}{ Gender } & Female & 39 & 25.3 & \multirow{2}{*}{$\begin{array}{c}\text { Marital } \\
\text { status }\end{array}$} & Married & 110 & 71.4 \\
\hline & Male & 115 & 74.7 & & Single & 44 & 28.6 \\
\hline \multirow{5}{*}{$\begin{array}{l}\text { Working } \\
\text { experience tourism } \\
\text { sector }\end{array}$} & 0-1 Year & 2 & 1.3 & \multirow{5}{*}{$\begin{array}{l}\text { Working } \\
\text { experience in the } \\
\text { hotel }\end{array}$} & $0-1$ Year & 37 & 24.0 \\
\hline & 2-3 Year & 1 & 0.6 & & 2-3 Year & 41 & 26.6 \\
\hline & 4-6 Year & 12 & 7.8 & & 4-6 Year & 30 & 19.5 \\
\hline & 7-11 Year & 25 & 16.3 & & 7-11 Year & 21 & 13.6 \\
\hline & $\begin{array}{c}12 \text { Year and } \\
\text { over }\end{array}$ & 114 & 74.0 & & $\begin{array}{l}12 \text { Year and } \\
\text { over }\end{array}$ & 25 & 16.3 \\
\hline \multirow{2}{*}{$\begin{array}{c}\text { Work status at } \\
\text { hotel }\end{array}$} & Seasonal & 42 & 27.3 & \multirow{3}{*}{ Department } & Front office & 41 & 26.6 \\
\hline & Permanent & 112 & 72.7 & & $\begin{array}{l}\text { Food and } \\
\text { beverage }\end{array}$ & 66 & 42.9 \\
\hline \multirow{5}{*}{ Education } & Primary & 8 & 5.2 & & Housekeeping & 47 & 30.5 \\
\hline & Secondary & 39 & 25.3 & \multirow{4}{*}{ Age } & $24-29$ & 17 & 11.0 \\
\hline & $\begin{array}{c}\text { Associate } \\
\text { degree }\end{array}$ & 45 & 29.2 & & $30-35$ & 25 & 16.3 \\
\hline & $\begin{array}{l}\text { Under } \\
\text { graduate }\end{array}$ & 48 & 31.2 & & $36-41$ & 39 & 25.3 \\
\hline & Graduate & 14 & 9.1 & & 42 and over & 73 & 47.4 \\
\hline
\end{tabular}

When these findings are analyzed, it is seen that 39 female and 115 male managers participated in the study. This situation indicates that approximately $75 \%$ of the participants are male managers. When the findings regarding the age of the administrators were examined, it was found that the overall age was between 36 and over (72.7\%). In addition, $69.5 \%$ of the managers who participated in the research have associate degree and postgraduate education. When the departments where the managers work are examined, it is observed that the front office consists of 41 people, 66 food and beverage and housekeeping 47 people, and most of them $(74 \%)$ have 12 years or more of experience in the tourism sector.

\subsection{Reliability Analysis}

In the evaluation of the Cronbach Alpha coefficient, the results of the analysis carried out considering that the values in the range of $0.00 \leq \alpha<0.60$ are reliable and the values in the range of $0.00 \leq \alpha<0.80$ are quite reliable (Kalayc1, 2005); It was determined that only the dimension of "importance attached to speed $(\alpha=0.680)$ " of a type personality trait has sufficient reliability coefficient. Therefore, the dimensions of "importance attached to work", "importance attached to time" and avoiding social activities were not included in the analysis. In addition, it was determined that the reliability coefficients of one-dimensional mental wellbeing $(\alpha=0.852)$ and task performance $(\alpha=0.875)$ were also sufficient for analysis. The values obtained from the performed normality analysis are as follows; emphasis on speed (Skewness: 1.013; 0.195 and Kurtosis: 2.142; 0.389), mental well-being (Skewness: -0.233 ; 0.195 and Kurtosis: 0.044; 0.389) and performance (Skewness: $-0.705 ; 0.195$ and Kurtosis: 0.230; 0.389). In this direction, considering that the relevant normality values vary between +3 and -3 (Amin et al., 2019; Middleton, 2018), exploratory and confirmatory factor analyzes were applied. 
Explanatory factor analysis of importance attached to speed, which is a dimension of type a personality trait, is presented in the Table 2 .

Table 2. Explanatory factor analysis of the importance attached to speed dimension of Type A Personality Scale

\begin{tabular}{lc}
\hline Scale Items & $\begin{array}{c}\text { Factor } \\
\text { loadings }\end{array}$ \\
\hline 1. I emphasize some important words while speaking. & 0.694 \\
\hline $\begin{array}{l}\text { 13. I think that I should work harder instead of developing myself and spending time on social } \\
\text { issues. }\end{array}$ & 0.556 \\
\hline 17. I attribute my successes to my ability to work quickly. & 0.525 \\
\hline 18. I feel that things need to be done immediately and quickly. & 0.732 \\
\hline 19. I constantly try to find more effective ways to get things done. & 0.803 \\
\hline Total Variance & 44.923 \\
\hline Keiser-Meyer-Olkin & 0.740 \\
\hline Barlett Sphericity & 120.140 \\
\hline
\end{tabular}

According to the analysis results in Table 2, the total variance explained is 44.923 . This value is within acceptable limits since the total variance explained by all factors is at least $30 \%$ in one-dimensional analyzes and at least 50\% in multidimensional analyzes (Gürbüz \& Şahin, 2014). A Kaiser-Meyer-Olkin (KMO) value of 0.60 and above indicates that the sample will be sufficient for factor analysis (Seçer, 2015). Therefore, it can be stated that the KMO value obtained as a result of this research is sufficient $(\mathrm{KMO}=0.740)$. In addition, when the Barlett sphericity test results were examined, it was found that the Chi-square $\left(X^{2}{ }_{(154)}=120.140 ; p\right.$ $<0.001)$ value was significant (Kalayc1, 2008).

As a result of the factor analysis, "3. I believe that children should be encouraged to be competitive." and "14. I make plans to do more in less time." questions were excluded from the evaluation due to overloading other factors. As a result of this process, Confirmatory Factor Analysis (CFA) was applied to measure construct validation. The purpose of applying the CFA analysis is to verify the validity of the structure and decomposition of research scales (Rathus \& Nevid, 2016, Batıgün \& Şahin, 2006; Özdevecioğlu et al., 2014; Sparrow et al., 2010; Keldal, 2015; Tennant et al., 2007) that have been determined in many studies before. In the analysis carried out on the dimension of giving importance to speed, it was determined that the construct validity was ensured $(\mathrm{RMSEA}=0.028, \mathrm{GFI}=0.970, \mathrm{AGFI}=0.941, \mathrm{CFI}=0.987$ and CMIN/DF 1.124). Explanatory factor analysis results regarding mental well-being scale are included in Table 3.

Table 3. Explanatory factor analysis of Mental Well-Being Scale

\begin{tabular}{lc}
\hline Scale Items & Factor loadings \\
\hline 2. I've been feeling useful. & 0.643 \\
\hline 6. I've been dealing with problems well. & 0.709 \\
\hline 7. I've been thinking clearly. & 0.884 \\
\hline 8. I've been feeling good about myself. & 0.774 \\
\hline 9. I've been feeling close to other people. & 0.555 \\
\hline 10. I've been feeling confident. & 0.794 \\
\hline 11. I've been able to make up my own mind about things. & 0.811 \\
\hline Total Variance & 54.661 \\
\hline Keiser-Meyer-Olkin & 0.877 \\
\hline Barlett Sphericity & 429.516 \\
\hline
\end{tabular}

The Kaiser-Meyer-Olkin (KMO) value found for the suitability of the sample in the Explanatory factor analysis performed for the mental well-being scale is 0.877 . As a result of Bartlett test, the approximate chi-square value is $X_{(154)}^{2}=120.140(\mathrm{p}<0.001)$. These values indicate the suitability of using factor analysis (Kalayc1, 2008). In factor analysis; "1. I've been feeling optimistic about the future.", "3. I've been feeling relaxed.", "4. I've been feeling interested in other people.", "5. I've had energy to spare.", "12. I've been feeling loved.", "13. 
I've been interested in new things." and "14. I've been feeling cheerful." statements were omitted due to excessive burden on other questions. As a result of the second analysis, the mental well-being scale was collected under one dimension as in the original form. After the obtained values, confirmatory factor analysis was applied to measure the construct validity. As a result of this analysis; RMSEA $=0.070, \mathrm{GFI}=0.955, \mathrm{AGFI}=0.911, \mathrm{CFI}=0.975$ and $\mathrm{CMIN} / \mathrm{DF}=1.760$. Explanatory factor analysis of task performance, which is a dimension of performance, is presented in the Table 4.

Table 4. Explanatory factor analysis of regarding the task performance dimension of Performance Scale

\begin{tabular}{lc}
\hline Scale Items & $\begin{array}{c}\text { Factor } \\
\text { loadings }\end{array}$ \\
\hline 1. I complete my business goals successfully. & 0.653 \\
\hline 2. I meet the performance criteria required by my job. & 0.776 \\
\hline 3. I use my expertise in all tasks related to my job. & 0.754 \\
\hline 4. I fulfill all the requirements of my job. & 0.838 \\
\hline 5. I can take on more than the assigned responsibilities for the tasks. & 0.537 \\
\hline 6. I think I am suitable for a higher-level role. & 0.505 \\
\hline 7. I am competent in all areas of work; I can master the tasks. & 0.867 \\
\hline 8. Perform well in my job by doing my duties as expected. & 0.835 \\
\hline 9. I work in a planned and organized way to achieve the targeted works and finish them on the & 0.784 \\
\hline given date. & 54.508 \\
\hline Total Variance & 0.889 \\
\hline Keiser-Meyer-Olkin & 706.257 \\
\hline
\end{tabular}

According to the analysis results in Table 4, task performance is collected under one dimension as in the original scale. The Kaiser-Meyer-Olkin (KMO) value obtained as a result of the analysis is 0.889 . The approximate chi-square value in the Bartlett test result is $\mathrm{X}_{(154)}^{2}=$ 706.257 ( $\mathrm{p}<0.001$ ). These values indicate the suitability of using factor analysis (Kalayc1, 2008). The values obtained as a result of the CFA analysis are as follows; RMSEA $=0.071$, $\mathrm{GFI}=0.942, \mathrm{AGFI}=0.896, \mathrm{CFI}=0.972$ and $\mathrm{CMIN} / \mathrm{DF}=1.768$. In addition, summary values for all three scales are presented in Table 5. These results show that all three scales used in the study provide a suitable value of structure and decomposition validity (Bentler \& Bonett, 1980; Gürbüz \& Şahin, 2014).

Table 5. Summary values for CFA analysis

\begin{tabular}{cccccc}
\hline Index & Normal values & Acceptable values & $\begin{array}{c}\text { Importance attached to } \\
\text { speed }\end{array}$ & $\begin{array}{c}\text { Mental well } \\
\text { being }\end{array}$ & $\begin{array}{c}\text { Task } \\
\text { performance }\end{array}$ \\
\hline$\chi 2 /$ sd & $0 \leq \chi 2 / \mathrm{sd} \leq 3$ & $3 \leq \chi 2 / \mathrm{sd} \leq 5$ & 1.124 & 1.760 & 1.768 \\
GFI & $0.95 \leq \mathrm{GFI} \leq 1.00$ & $0.90 \leq \mathrm{GFI} \leq 0.95$ & 0.970 & 0.955 & 0.942 \\
AGFI & $0.90 \leq \mathrm{AGFI} \leq 1.00$ & $0.85 \leq \mathrm{AGFI} \leq 0.90$ & 0.941 & 0.911 & 0.896 \\
CFI & $0.95 \leq \mathrm{CFI} \leq 1.00$ & $0.90 \leq \mathrm{CFI} \leq 0.95$ & 0.987 & 0.975 & 0.972 \\
RMSEA & $0.00 \leq \mathrm{RMSEA} \leq$ & $0.05 \leq \mathrm{RMSEA} \leq$ & 0.028 & 0.070 & 0.071 \\
\hline
\end{tabular}

\subsection{Correlation Analysis}

In the interpretation of the correlation values, it is known that the value between 0.26 0.46 is weak, the value between $0.50-0.69$ is medium and the value between $0.90-1.00$ is high (Köse, 2012). As a result of the analysis carried out by taking these values into account, it has been determined that type a personality trait have a positive and highly significant relationship with each other, the dimension of importance attached to speed, task performance and mental well-being. Findings regarding the analysis in question are included in Table 6. 
Table 6. Findings regarding correlation analysis

\begin{tabular}{|c|c|c|c|c|c|}
\hline $\mathrm{n}=154$ & Mean & S.D. & 1 & 2 & 3 \\
\hline 1. Importance Attached to Speed & 4.0208 & 0.5334 & $(0.680)$ & & \\
\hline 2. Task Performance & 4.3016 & 0.5564 & $0.593 * * *$ & $(0.852)$ & \\
\hline 3. Mental Well-Being & 4.1271 & 0.5715 & $0.702 * * *$ & $0.531 * * *$ & $(0.875)$ \\
\hline
\end{tabular}

\subsection{Regression Analysis}

Multiple regression analysis was conducted to test the research hypotheses. In the model in which two hypotheses are tested, there is no multicollinearity problem "Tolerance> 0.2 and VIF <10” (Gürbüz \& Şahin, 2014). Type a personality trait consist of four dimensions: importance attached to work, avoiding social activities, importance attached to speed and importance attached to timing. However, as stated in the reliability analysis section of the study, only the importance attached to speed was included in the analysis.

Table 7. Results of multiple regression analysis for testing hypotheses

\begin{tabular}{cccccc}
\hline \multirow{2}{*}{$\mathrm{n}=154$} & \multicolumn{4}{c}{ Task performance } \\
\cline { 2 - 6 } & $\mathrm{B}$ & Std. Error & $\beta$ & $\mathrm{t}$ & $\mathrm{p}$ \\
\hline Constant & 1.571 & 0.288 & - & 5.448 & 0.000 \\
\hline $\mathrm{H}_{1 .}$ Importance Attached to Speed & 0.454 & 0.094 & 0.435 & 4.830 & $0.000^{* * *}$ \\
\hline $\mathrm{H}_{2 .}$ Mental Well-Being & 0.219 & 0.088 & 0.225 & 2.501 & $0.013^{* *}$ \\
\hline Tolerance $=0.50$ & $\mathrm{VIF}=1.97$ & $\mathrm{R}=0.615$ & $\mathrm{R}^{2}=0.378$ & $\mathrm{~F}=45.849$ & 0.000 \\
\hline
\end{tabular}

$* * * \mathrm{p}<0.001 ; * * \mathrm{p}<0.01$

Accordingly, when the analysis result in Table 7 is examined, it is seen that the effect of the importance attached to speed on task performance can be explained with a significance of 0.000 at $37 \%$ level $\left(\mathrm{R}^{2}=0.378\right)$. Hence " $\boldsymbol{H}_{1}$. Type-a personality traits has positive effect on task performance." The first hypothesis of the research expressed in the form was partially supported $(\beta=0.435 ; \mathrm{p}<0.001)$. Result shows that hotel managers have the importance attached to speed, expressed as active, impatient and impatient behaviors, and personality trait has a quality that increases task performance. The effect of mental well-being on task performance is explained with a significance of 0.01 at the $37 \%$ level $\left(\mathrm{R}^{2}=0.378\right)$. Therefore, the second hypothesis of the research, expressed as " $\boldsymbol{H}_{2}$. Mental well-being has positive effect on task performance.", was supported $(B=0.225 ; \mathrm{p}<0.01)$. As a result of the obtained results, it was found that the mental well-being levels of hotel managers are high and so that such situation has an increasing effect on the task performance. In line with the regression analysis findings, result of research model is presented in Figure 2.

Figure 2. Result of research model

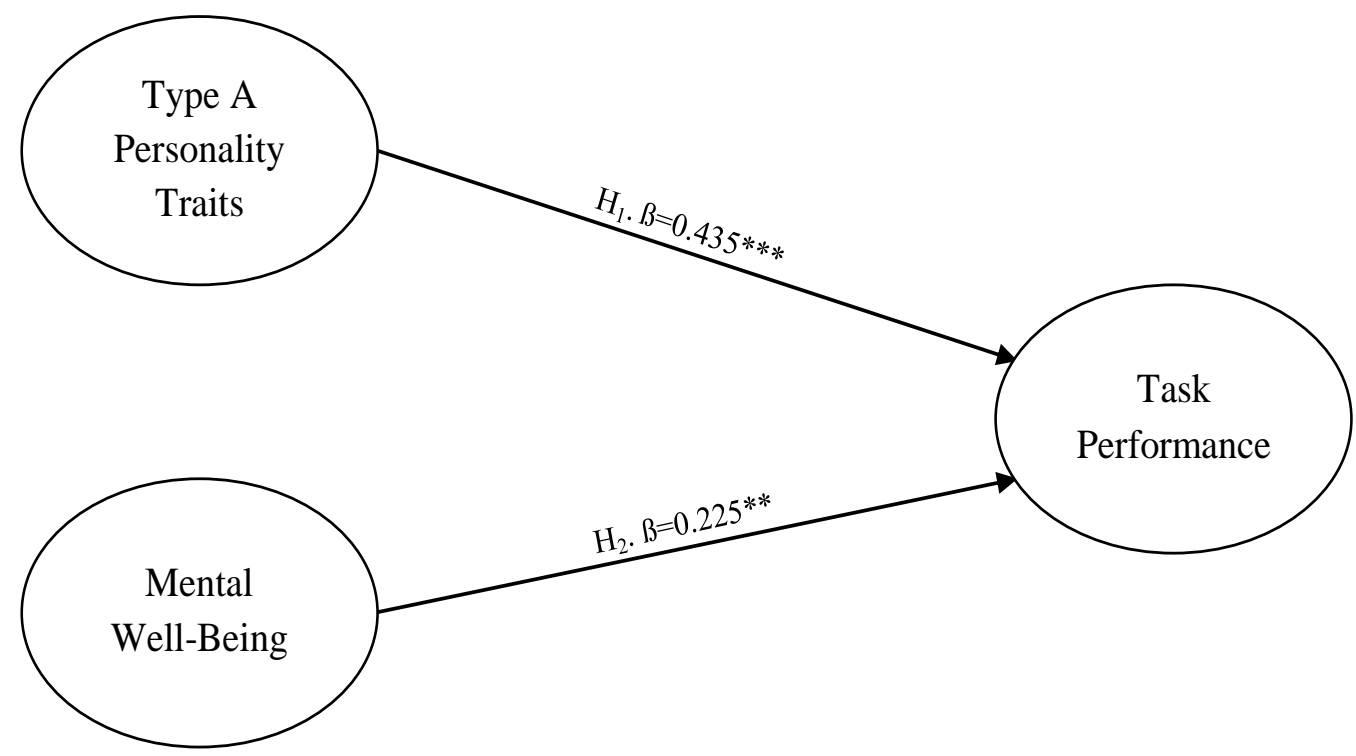




\section{Conclusion}

This research was carried out to determine the effect of type-a personality traits and mental well-being on task performance. According to the results of the current research, it has been found that the mental well-being and type a personality traits of hotel managers have a positive and significant effect on task performance. This result shows that hotel managers have high levels of well-being and that type-a personality traits have a positive effect on task performance. However, when other studies in the literature are examined, findings regarding the positive relationship of the type a personality with concepts such as stress are encountered (Batıgün \& Şahin, 2006). In this case, there is a question about whether type a personality has a negative effect in all circumstances. For example, in a study where type a personality was evaluated together with concepts such as ineffective coping, anger and job obsession, it is known that the stress scores of type-a individuals are significantly higher and they use ineffective coping methods (Şahin, Basım \& Akkoyun, 2011). Based on this, it can be stated that type a individuals tend to exhibit aggression and explosive anger, excessive defense or passivation and withdrawal behavior. In a study conducted by Tokat, Kara \& Kara (2013), it was concluded that type-a individuals are not inclined to support organizational change. In another study conducted by Üzüm \& Şenol (2020), it was found that type a personality has a positive effect on involuntary absenteeism, which is a dimension of absenteeism. In addition, as a result of the study carried out by Yavuz \& Kayhan (2020), the fact that individuals with type a personality trait are more likely to be absent at work reflects another negative characteristic of type-a personality. Another study in the sample of five-star hotels also shows similar results. In the study, the relationship between a and b type personality structure and attacks on selfdisclosure and attacks on social relations are mentioned (Avc1 \& Kaya, 2010).

The finding about the effect of type a personality on task performance, obtained within the scope of this study, has a qualification that expresses a different aspect of other research findings in the literature. This qualification can be explained by the contribution made to the self-determination (SD) theory. In SD theory, there are three basic psychological needs called competence, relatedness and autonomy (Ryan \& Deci, 2001). The fact that these needs are provided in the individual positively affects mental well-being, while the fact that they are not met results in a decrease in mental well-being (Ryan \& Deci, 2001). One of these psychological needs, the need for autonomy, is the individual's determination of his own behavior and acceptance of the possible consequences of these behaviors (Williams \& Deci, 1996). One of these possible consequences is that individuals exhibiting type-a personality traits exert more effort than expected in their tasks. Despite the stressful working conditions, mental well-being increases in managers who exhibit high job performance. This increase is also supported by current research results. However, an important problem at this point is how mental well-being changes in the long term. As a matter of fact, considering the labor-intensive structure of the tourism sector and the importance of the human factor (Kozak, 2001), it is likely that the activities at the management level will consume individuals both physically and mentally. It can be assumed that this burnout is more likely, considering the different cultures and values of the employees in the sector. Therefore, there is a need to examine mental well-being of type-a managers with a stressful lifestyle through longitudinal studies. Currently, it is thought that the underlying reason for the high mental well-being and task-performance-oriented work of managers with type a personality trait working in hotel enterprises should be examined through qualitative research. In addition, the fact that mental well-being does not have a tool or regulatory effect and that only the dimension of importance attached to speed of type a personality has been analyzed is another result of the necessity for future studies. It is a limitation that the research sample is limited to the administrators working in the province of Alanya. The main reason for this limitation is that it is not possible to reach 685 five-star hotels in Turkey $(\mathrm{KTB}, 2017)$ in terms of both time and cost. Therefore, it is thought that the preference of stratified sampling method, the use of longitudinal research method, and in-depth interviews with qualitative research will contribute to the relevant literature. 


\section{References}

Adler, A. (1964). Social interest: A challenge to mankind. New York: Capricorn Books.

Alanya Ticaret Sanayi Odasi (2019). Alanya Ekonomik Raporu 2019. https://www.altso.org.tr/dosya-goruntuleyici/?id=342826\&rp=342824. (Erişim Tarihi:01.01.2021).

Alanya Turistik İşletmeciler Derneği (2020). Tesis kapasite raporu. https://www.altid.org.tr/bilgi-hizmetleri/alanya-tesis-kapasite/ (Erişim Tarihi: 01.01.2021).

Al-Mashaan, O. S. (2001). Job stress and job satisfaction and their relation to neuroticism, type a behavior, and locus of control among Kuwaiti personnel. Psychological Reports, 88(3), 1145-1152.

Amin, A., Shah, B., Khattak, A. M., Moreira, F. J. L., Ali, G., Rocha, A., \& Anwar, S. (2019). Cross-company customer churn prediction in telecommunication: a comparison of data transformation methods. International Journal of Information Management, 46(2), 304-319.

Avcı, U. ve Kaya, U. (2010). Yıldırma (mobbing) ve kişilik ilişkisi: hizmet sektörü çalışanları üzerinde bir araştırma. Afyon Kocatepe Üniversitesi, Íktisadi ve İdari Bilimler Dergisi, 12(2), 51-79.

Bağcı, Z. (2014). Çalışanların iş doyumunun görev ve bağlamsal performansları üzerindeki etkisi. Yönetim ve Ekonomi Araştırmaları Dergisi, 12(24), 58-72.

Bakker, A. B., Demerouti, E., \& Lieke, L. (2012). Work engagement, performance, and active learning: the role of conscientiousness. Journal of vocational behavior, 80(2), 555-564.

Batıgün, A. D., ve Şahin, N. H. (2006). İş stresi ve sağlık psikolojisi araştırmaları için iki ölçek: a-tipi kişilik ve iş doyumu. Türk Psikiyatri Dergisi, 17(1), 32-45.

Baytemir, K. (2016). Ergenlikte ebeveyn ve akrana bağlanma ile öznel iyi oluş arasındaki ilişkide kişilerarası yeterliğin aracılığı. Eğitim ve Bilim, 41(186), 59-91.

Bentler, P. M., \& Bonett, D. G. (1980). Significance tests and goodness of fit in the analysis of covariance structures. Psychological bulletin, 88(3), 588.

Borman, W. C., \& Motowidlo, S. J. (1997). Task performance and contextual performance: the meaning for personnel selection research. Human performance, 10(2), 99-109.

Burger, J. M. (2006) Kişilik: psikoloji Biliminin İnsan Doğasına Dair Söyledikleri. İstanbul: Kaktüs Yayınları.

Can, A. (2018). SPSS ile bilimsel araştırma sürecinde nicel veri analizi. Ankara: Pegem Atıf İndeksi.

Carr, A. (2016). Positive psychology the science of human happiness and strength. London: Routlage.

Ceyhan, S., ve Çiçek, H. (2020). Ortaöğretim kurumlarında görev yapan öğretmenlerin a tipi kişilik özelliklerinin tükenmişlik üzerindeki etkisinde genel sinizmin aracı rolü. Abant İzzet Baysal Üniversitesi Ĕgitim Fakültesi Dergisi, 20(2), 888-903.

Conway, J. M. (1999). Distinguishing contextual performance from task performance for managerial jobs. Journal of applied Psychology, 84(1), 3-13.

Deci, E. L., \& Ryan, R. M. (2000). The what and why of goal pursuits: human needs and the self-determination of behavior. Psychological inquiry, 11(4), 227-268.

Dembroski, T. M., \& Costa J. P. T. (1987). Coronary prone behavior: components of the type a pattern and hostility. Journal of personality, 55(2), 211-235. 
Demirtaş, A. S., Baytemir, K., ve Güllü, A. (2018). Pedagojik formasyon öğrencilerinde umut ve mental iyi oluş: yapılandırmacı düşünmenin arac1 rolü. Mersin Üniversitesi Eğitim Fakültesi Dergisi, 14(1), 317-331.

Diaz-Vilela, L. F., Rodríguez, N. D., Isla-Díaz, R., Díaz-Cabrera, D., Hernández-Fernaud, E., \& Rosales-Sánchez, C. (2015). Relationships between contextual and task performance and interrater agreement: Are there any?. PloS one, 10(10), 1-13, e0139898.

Diener, E., \& Chan, M. Y. (2011). Happy people live longer: subjective well-being contributes to health and longevity. Applied Psychology: Health and Well-Being, 3(1), 1-43.

Diener, E. D., \& Suh, M. E. (1997). Subjective well-being and age: an international analysis. Annual review of gerontology and geriatrics, 17(1), 304-324.

DiPaola, M. F., \& Hoy, W. K. (2005). Organizational citizenship of faculty and achievement of high school students. The high school journal, 88(3), 35-44.

Fredrickson, B. (2009). Positivity: top-notch research reveals the 3-to-1 ratio that will change your life. New York: Harmony Publishing.

Fromm, B. (1942). Blood and banquets: a berlin social diary. New York: Harper \& Brothers Publishing.

Fromm, E. (1944). Individual and social origins of neurosis. American Sociological Review, 9(4), 380-384.

Fuller-Iglesias, H. R. (2015). Social ties and psychological well-being in late life: the mediating role of relationship satisfaction. Aging \& Mental Health, 19(12), 1103-1112.

Goodman, S. A., \& Svyantek, D. J. (1999). Person-organization fit and contextual performance: do shared values matter. Journal of vocational behavior, 55(2), 254-275.

Gözmen, A., ve Aşç1, F. H. (2016). Sporcularda optimal performans duygu durumunun yordanmasında beş faktörlü kişilik özelliklerinin ve mükemmeliyetçiliğin rolü. Spor Bilimleri Dergisi, 27(1), 40-48.

Gürbüz, S., ve Şahin, F. (2014). Sosyal bilimlerde araştırma yöntemleri. Ankara: Seçkin Yayıncilik.

Güvendi, B., Işım, A. T., ve Güçlü, M. (2018). Korumalı futbol (amerikan futbol) sporcularının kişilik özellikleri ve psikolojik performans stratejileri ile karar verme stilleri arasındaki ilişki. İstanbul Üniversitesi Spor Bilimleri Dergisi, 8(2), 159-175.

Harmanc1, Y. K. (2018). Örgütsel yaşamda kişilik ve performans ilişkisinde pozitif duygusallığın aracı rolü. İşletme Araştırmaları Dergisi, 10(1), 321-341.

Hatipoğlu, Z., Akduman, G., ve Demir, B. (2019). Babacan liderlik tarzının çalışan görev performansı ve duygusal bağl1lı üzerindeki etkisi. Işsletme Araştırmaları Dergisi, 11(1), 279-292.

Hogan, R. (1994). Trouble at the top: causes and consequences of managerial incompetence. Consulting Psychology Journal: Practice and Research, 46(1), 9.

Howard, K. I., Kopta, S. M., Krause, M. S., \& Orlinsky, D. E. (1986). The dose-effect relationship in psychotherapy. American psychologist, 41(2), 159.

İlhan, M., ve Çetin, B. (2014). Lısrel ve amos programları kullanılarak gerçekleştirilen yapısal eşitlik modeli (yem) analizlerine ilişkin sonuçların karşılaştırılması. Eğitimde ve Psikolojide Ölçme ve Değerlendirme Dergisi, 5(2), 26-42. 
İlhan, T., ve Özbay, Y. (2010). Yaşam amaçlarının ve psikolojik ihtiyaç doyumunun öznel iyi oluş üzerindeki yordayıc1 rolü. Turkish Psychological Counseling \& Guidance Journal, 4(34), 109-116.

Imtiaz, S., \& Kamal, A. (2016). Rumination, optimism, and psychological well-being among the elderly: self-compassion as a predictor. Journal of Behavioural Sciences, 26(1), 32-50

Jawahar, I. M., \& Ferris, G. R. (2011). A longitudinal investigation of task and contextual performance influences on promotability judgments. Human Performance, 24(3), 251-269.

Kalayc1, G., Albayrak, S. A., Eroğlu, A., Küçüksille, E., ve Ak, B. (2005). SPSS uygulamali çok değişkenli istatistik teknikleri. Ankara: Asil Yayın Dağıtım.

Kalayc1, S. (2008). SPSS uygulamalı çok degişkenli istatistik teknikleri. Ankara: Asil Yayincilik, 131-167.

Katz, D. (1964). The motivational basis of organizational behavior. behavioral science, 9(2), 131-146.

Keenan, A., \& McBain, G. D. M. (1979). Effects of type a behaviour, intolerance of ambiguity, and locus of control on the relationship between role stress and work-related outcomes. Journal of Occupational Psychology, 52(4), 277-285.

Keldal, G. (2015). Warwick-edinburgh mental iyi oluş ölçeği'nin türkçe formu: geçerlik ve güvenirlik çalışması. The Journal of Happiness \& Well-Being, 3(1), 103-115.

Keyes, C. L. (2005). Mental illness and/or mental health? investigating axioms of the complete state model of health. Journal of consulting and clinical psychology, 73(3), 539-548.

Keyes, C. L., Myers, J. M., \& Kendler, K. S. (2010). The structure of the genetic and environmental influences on mental well-being. American Journal of Public Health, 100(12), 2379-2384.

Khallad, Y., \& Jabr, F. (2016). Effects of perceived social support and family demands on college students' mental well-being: a cross-cultural investigation. International Journal of Psychology, 51(5), 348-355.

Khan, Z., \& Zadeh, Z. F. (2014). Mindful eating and it's relationship with mental wellbeing. Procedia-Social and Behavioral Sciences, 159, 69-73.

Knox, J. (2003). Archetype, attachment, analysis: jungian psychology and the emergent mind. England: Psychology Press.

Köknel, Ö. (2005). Kaygıdan mutluluğa kişilik. İstanbul: Altın Kitaplar.

Köse, S. K. (2012). Korelasyon ve regresyon analizi. Türk Toraks Derneği 8.Yıllık Kongresi, Antalya.

Kottke, T. E., Stiefel, M., \& Pronk, N. P. (2016). Well-being in all policies: promoting crosssectoral collaboration to improve people's lives. Preventing chronic disease, 13(52), 1-13.

Kozak, M. (2001). Türkiye'de konaklama sektörü ve çalışan kadınların tükenmişlik durumlari üzerine bir araştirma. Gazi Üniversitesi Turizm Akademik Dergisi, 2(2001). 11-12.

Kültür ve Turizm Bakanlığı (2017). T.C. Kültür ve Turizm Bakanlı̆gl Yatırım ve Issletmeler Genel Müdürlügü 2016 Yllı İşletme Belgeli Konaklama Tesislerine Giriş ve Geceleme Saylları. http://yigm.kulturturizm.gov.tr/TR,9579/turizm-tesisleri (Erişim tarihi: 16.01.2021).

Liang, J., Lan-xiang, P., Si-jie, Z., \& Wu, H. (2017). Relationship among workplace spirituality, meaning in life, and psychological well-being of teachers. Universal Journal of Educational Research, 5(6), 1008-1013.

Luthans, F. (2011). Organizational Behavior, New York: McGraw-Hill Companies. 
Lyubomirsky, S., King, L., \& Diener, E. (2005). The benefits of frequent positive affect: Does happiness lead to success?. Psychological bulletin, 131(6), 803-855.

Middleton, T. (2018). The effectiveness of the three-module job training intervention on job search knowledge, job search attitude knowledge, and job survival/maintenance knowledge. Schoolar works, 5, 2-184.

Mohammed, S., John, E. M., \& 'Bart'Bartlett, A. L. (2002). Technical-administrative task performance, leadership task performance, and contextual performance: considering the influence of team-and task-related composition variables. Journal of Organizational Behavior: The International Journal of Industrial, Occupational and Organizational Psychology and Behavior 23(7), 795-814.

Ocak, M., ve Güler, M. (2019). A tipi kişilik ve başa çıkma yöntemlerinin stresle ilişkisi: Türk ve Bosnalı öğrenciler üzerinde karşılaştırmalı bir araştırma. Mehmet Akif Ersoy Üniversitesi Sosyal Bilimler Enstitüsü Dergisi, 5(8), 135-147.

Organ, D. W. (1977). A reappraisal and reinterpretation of the satisfaction-causes-performance hypothesis. Academy of management Review, 2(1), 46-53.

Organ, D., W. (1988). Organizational citizenship behavior: The good soldier syndrome. New York: Lexington Books/DC Heath and Company.

Özcan, E. D., ve Behram, N. K. (2013). A tipi kişilik özelliklerinin işkoliklik eğilimi üzerine etkisi: başarı için çabalama ve tahammülsüzlük/asabiyet boyutları açısından bir değerlendirme. Sakarya İktisat Dergisi, 2(4), 85-110.

Özdevecioğlu, M., ve Kanı̈ür, S. (2009). Çalışanların ilişki ve görev yönelimli liderlik algılamalarının performansları üzerindeki etkileri. Karamanoğlu Mehmetbey Üniversitesi Sosyal ve Ekonomik Araştırmalar Dergisi, 2009(1), 53-82.

Özdevecioğlu, M., Mahmut, A., Karaca, M., ve İştahlı, B. (2014). Kötü niyetli yönetim algılamasının çalışanların performansları üzerindeki etkisinde duygusal zekânın rolü. Çankırı Karatekin Üniversitesi İktisadi ve İdari Bilimler Fakültesi Dergisi, 4(1), 1-18.

Pekdemir, I., ve Koçoğlu, M. (2014). İşkoliklik ile iş yaşam dengesi arasındaki ilişkide kişilik özelliklerinin aracılık rolü üzerine bir araştırma. Abant İzet Baysal Üniversitesi Sosyal Bilimler Enstitüsü Dergisi, 14(1), 309-338.

Pelit, E., ve Öztürk, Y. (2010). Otel işletmeleri işgörenlerinin iş doyum düzeyleri: sayfiye ve şehir otel işletmeleri işgörenleri üzerinde bir araştırma. İşletme Araştırmaları Dergisi, 2(1), 43-72.

Podsakoff, P. M., MacKenzie, S. B., Paine, J. B., \& Bachrach, D. G. (2000). Organizational citizenship behaviors: a critical review of the theoretical and empirical literature and suggestions for future research. Journal of management, 26(3), 513-563.

Polatc1, S. (2014). Psikolojik sermayenin görev ve baglamsal performans üzerindeki etkileri: polis teskilatinda bir arastirma. Ege Akademik Bakis, 14(1), 115.

Price, V. A. (1982). Type A behavior pattern: A model for research and practice. Cambridge: Academic Press.

Rathus, S. A., \& Nevid, J. S. (1989). Stress: what it is and what it does. Psychology and the challenges of Life. Adjustment and Growth, 181-229.

Rayburn, J. M., \& Rayburn, L. G. (1996). Relationship between machiavellianism and type a personality and ethical-orientation. Journal of Business Ethics, 15(11), 1209-1219.

Ryan, R. M., \& Deci, E. L. (2001). On happiness and human potentials: a review of research on hedonic and eudaimonic well-being. Annual review of psychology, 52(1), 141-166. 
Ryff, C. D., \& Singer, B. H. (2008). Know thyself and become what you are: a eudaimonic approach to psychological well-being. Journal of happiness studies, 9(1), 13-39.

Sackett, P. R., \& DeVore, C., J. (2002). Counterproductive behaviors at work. Handbook of industrial, work and organizational psychology, 1, 145-154.

Şahin, N. H., Basım, H. N., ve Akkoyun, N. (2011). A-tipi kişilik ve stres ilişkisinde üç önemli bileşen: öfke, etkisiz başa çıkma ve iş saplantısı. Türk Psikoloji Dergisi, 26(68), 31-44.

Seçer, İ. (2015). Üniversite öğrencilerinde okul tükenmişliği ile psikolojik uyumsuzluk arasındaki ilişkinin incelenmesi. Atatürk Üniversitesi Sosyal Bilimler Enstitüsü Dergisi, 19(1), 81-99.

Serbest, F. (2000). İş yaşamı niteliği. Verimlilik Dergisi, 2(2000), 21-35.

Sonnentag, S., \& Frese, M. (2002). Performance concepts and performance theory. Psychological management of individual performance, 23(1), 3-25.

Sparrow, P. R., Chadrakumara, A., \& Perera, N. (2010). Impact of work values and ethics on citizenship and task performance in local and foreign invested firms: a test in a developing country context. Sdyney Bussiness School, Research Online, 32, 2-36.

Stevenson, P. H., Sung, S. M., Pai, T., \& Lyman, R. S. (1937). Chinese constitutional differentiation and Kretschmerian typology. Human Biology, 9(4), 451-482.

$\mathrm{Su}, \mathrm{H}$. (2014). The factors of turnover intention in hotel industry. International Journal of Research and Reviews in Applied Sciences, 21(1), 31-38.

Tağraf, H. (2009). Personel istihdam sürecinin işletme performansina etkisi ve gaziantep ili tekstil sektöründe bir uygulama. Çukurova Üniversitesi Sosyal Bilimler Enstitüsü Dergisi, 18(2), 398-414.

Tarhan, S. (2012). Umudun özyeterlik, algılanan sosyal destek ve kişilik özelliklerinden yordanması. Doktora Tezi, Gazi Üniversitesi. Eğitim Bilimleri Enstitüsü, Ankara.

Tatar, A. (2017). Büyük beş-50 kişilik testinin türkçeye çevirisi ve beş faktör kişilik envanteri kısa formu ile karşılaştırılması. Anadolu Psikiyatri Dergisi, 18(1), 51-61.

Tennant, R., Hiller, L., Fishwick, R., Platt, S., Joseph, S., Weich, S., \& Stewart-Brown, S. (2007). the warwick-edinburgh mental well-being scale (wemwbs): development and UK validation. Health and Quality of life Outcomes, 5(1), 1-13.

Tokat, B., Kara, H., ve Kara, M. Y. (2013). AB tipi kişilik özelliklerine sahip işgörenlerin olas1 bir örgütsel değişime yatkınlıklarının araştırılması. Turkish Studies, 8(8), 1973-1988.

Türk Dil Kurumu (2020). Türkçe Sözlük: Performans. http://www.tdk.gov.tr/index.php?option=com_gts\&kelime=performans. (Erişim tarihi: 17.01.2021).

Uslu, Y. D. (2011). Örgütlerde yönetsel etkinliğe ulaşmada yeni bir yaklaşım: yaratıcı liderlik. Sosyal Ekonomik Araştırmalar Dergisi, 11(22), 419-444.

Üzüm, B., ve Şenol, L. (2020). Tip a ve tip b kişilik tipi ile devamsızlık ilişkisi: bir araştırma. İstanbul Ticaret Üniversitesi, Sosyal Bilimler Dergisi, 19(37), 257-267.

Viswesvaran, C., \& Ones, D. S. (2000). Perspectives on models of job performance. International Journal of Selection and Assessment, 8(4), 216-226.

Williams, G. C., \& Deci, E. L. (1996). Internalization of biopsychosocial values by medical students: a test of self-determination theory. Journal of personality and social psychology, 70(4), 767. 
World Health Organisation (2004). Promoting Mental Health; Concepts Emerging Evidence and Practice (Summary report). Geneva

Yaşin, T. (2016). Kişilik özellikleri ve psikolojik sermayenin psikolojik iyi oluş, akış deneyimi, iş tatmini ve çalışan performansına etkisi. Yüksek Lisans Tezi, Başkent Üniversitesi, Sosyal Bilimler Enstitüsü, İşletme Yönetimi Anabilim Dalı, Yönetim ve Organizasyon Bilim Dallı, Ankara.

Yaşlığlu, M. M. (2017). Sosyal bilimlerde faktör analizi ve geçerlilik: Keşfedici ve doğrulayıcı faktör analizlerinin kullanılması. İstanbul Üniversitesi İsletme Fakültesi Dergisi, 46, 74-85.

Yasmin, N., \& Khan, W. (2017). Character strengths and subjective well-being: An exploratory study of Indian youth. Indian Journal of Positive Psychology, 1, 174-177.

Yavuz, N., \& Kayhan, A. (2020). Presenteeism: a research on type a and type b personality and demographic features. İstanbul Ticaret Üniversitesi Sosyal Bilimler Dergisi, 19(37), 77-89.

Yin-Fah, B. C., Foon, Y. S., Chee-Leong, L., \& Osman, S. (2010). An exploratory study on turnover intention among private sector employees. International Journal of Business and Management, 5(8), 57-64.

Zopiatis, A., Constanti, P., \& Theocharous, A. L. (2014). Job involvement, commitment, satisfaction and turnover: Evidence from hotel employees in Cyprus. Tourism Management, 41, 129-140.

\section{ETİK ve BİLIMSEL İLKELER SORUMLULUK BEYANI}

$\mathrm{Bu}$ çalışmanın tüm hazırlanma süreçlerinde etik kurallara ve bilimsel atıf gösterme ilkelerine riayet edildiğini yazar(lar) beyan eder. Aksi bir durumun tespiti halinde Afyon Kocatepe Üniversitesi Sosyal Bilimler Dergisi'nin hiçbir sorumluluğu olmayıp, tüm sorumluluk makale yazarlarına aittir. Yazarlar etik kurul izni gerektiren çalışmalarda, izinle ilgili bilgileri (kurul adı, tarih ve sayı no) yöntem bölümünde ve ayrıca burada belirtmişlerdir.

Kurul adı: Burdur Mehmet Akif Ersoy Üniversitesi Girişimsel Olmayan Klinik Araştırmalar Etik Kurulu

Tarih: 02.12.2020

No: GO 2020/338 